\title{
Исследование шумов фемтосекундного волоконного эрбиевого лазера для оптимизации характеристик фемтосекундного синтезатора частот на его основе
}

\author{
$\underline{\text { А.А. Филонов }}^{1,{ }^{*}}$, Н.А. Коляда ${ }^{1}$, В.С. Пивцов ${ }^{1,2}$ \\ ${ }^{1}$ Институт лазерной физики СО РАН \\ ${ }^{2}$ Новосибирский государственный технический университет \\ *E-mail: aa.filonov@mail.ru
}

DOI: 10.31868/RFL2020.232-233

В последнее время все большее внимание уделяется прецизионным системам на основе волоконных лазеров. Одним из перспективных направлений является разработка и исследование транспортируемых фемтосекундных волоконных синтезаторов частот (СЧ)[1-2]. В таких системах осуществляется перенос стабильности выходных частот оптических стандартов в радиодиапазон. Транспортируемые СЧ могут использоваться для космической навигации, внелабораторной метрологии и т.д. Одним из путей развития волоконных СЧ является улучшение параметров фемтосекундного волоконного лазера, который используется как задающий генератор.

В данной работе проведено исследование выходных параметров фемтосекундного волоконного эрбиевого лазера, который является частью фемтосекундного синтезатора частот. Исследуемый лазер имеет три волоконных выхода в разных частях резонатора. С каждого из выходов на межмодовой частоте лазера (82,6 МГц) регистрировался уровень фазовых шумов для частот отстройки от 1 Гц до 1 МГц. Измерения проводились в режиме синхронизации мод лазера при токах лазерного диода накачки (3SPPhotonics) 0.55A, 0.75A и 0.99A (минимальный, средний и максимальный токи при которых поддерживается синхронизация мод). Фазовые шумы регистрировались при помощи анализатора сигналов Keysight E5052B. В ходе работ определены параметры диодного лазера накачки, которым соответствует минимальный уровень фазовых шумов выходного излучения лазера. Также определено место вывода лазерного излучения из резонатора с минимальным уровнем фазовых шумов.

Следующим этапом работ было уменьшение уровня фазовых шумов выходного излучения за счет применения пассивной стабилизации волоконного лазера. При применении кожуха из оргстекла толщиной 8 мм и термозвукоизолирующего материала удалось снизить уровень фазовых шумов излучения задающего лазера 15 - 25 дБн/Гц вблизи частот отстройки 3 Гц, 50 Гц, 150 Гц и на $\sim 5$ дБн/Гц на частотах $1-3$ Гц.

В результате проведенных работ удалось снизить уровень фазовых шумов радиочастотных сигналов на выходе фемтосекундного синтезатора частот около 10 дБн/Гц на частотах отстройки от сотен Гц до сотен кГц. Кроме того определены оптимальные параметры диодного лазера накачки волоконного лазера для осуществления долговременной стабилизации частот волоконного СЧ. 


\section{Литература}

[1] S. N. Bagayev, V. I. Denisov, et al Journal of Physics: Conf. Series, 793, 1-4 (2017)

[2] Droste S., Ycas G., et al Nanophotonics. 5, 196-213. (2016)

Научный руководитель - канд. физ.-мат. наук Н.А. Коляда 